\title{
12. A Commentary on Decision-making and Organisational Legitimacy in the Risk Society.
}

\author{
Suzanne Benn ${ }^{\mathrm{a}}$, Paul Brown ${ }^{\mathrm{b}}$ and Andrea North-Samardzic ${ }^{\mathrm{c}}$
}

\begin{abstract}
Key concepts of Risk Society as elaborated by Ulrich Beck and others (Beck, 1992; Beck, 1995; Beck, 1999; Giddens, 1994; Beck, Giddens and Lash1994; Beck, Bonss and Lau, 2003) are illuminated though a case study of managed environmental risk, namely the Hexachlorobenzene (HCB) controversy at Botany, a southeast suburb of Sydney. We observe the way multiple stakeholder decision-making plays out a number of Risk Society themes, including the emergence of 'unbounded risk' and of highly 'individualised' and 'reflexive' risk communities. Across several decades, the events of the HCB story support Risk Society predictions of legitimacy problems faced by corporations as they harness technoscientific support for innovation in their products and industrial processes without due recognition of social and environmental risk. Tensions involving identity, trust and access to expert knowledge advance our understanding of democratic 'sub-political' decision making and ways of distributing environmental risk.
\end{abstract}

Key words: Individualization, sub-politics, Risk Society, reflexivity

\footnotetext{
${ }^{a}$ School of Management, University of Technology Sydney, PO Box 123, Broadway NSW 2007 Australia; Ph 6129514 3059, Fax 6129514 3602, Email Suzanne.Benn@uts.edu.au

${ }^{\mathrm{b}}$ School of History and Philosophy, University of New South Wales, paul.brown@unsw.edu.au

c School of Organisation and Management, Faculty of Business, University of New South Wales, Sydney NSW 2052 Australia; andreans@unsw.edu.au
} 


\subsection{Introduction}

For more than two decades, a number of European sociologists have explicated the relationship between society and the natural environment through the lens of Risk Society theory (Beck, 1992; Beck, 1995; Beck, 1999; Giddens, 1994; Beck, Giddens and Lash1994; Beck Bonss and Lau, 2003; and others). This paper comments on how key concepts of Risk Society theory are inflected through stakeholder management of environmental risk associated with the management of over 10,000 tonnes of Hexachlorobenze (HCB) stored at the Orica chemicals plant in southeastern Sydney. The paper is best read in conjunction with other contributions in this special issue.

\subsection{Stages of Risk Society}

Risk Society theory has been highly influential on current perceptions of the relationship between nature and social life and organisation. Rather than relegating the natural environment to the natural sciences, Risk Society takes a conceptual leap by linking social awareness of environmental issues to a diminishing trust in the leading institutions of modernity. In Risk Society as elaborated by Beck and others (Beck, 1992; Beck, 1995; Beck, 1999; Giddens, 1994; Beck, Giddens and Lash, 1994; Beck Bonss and Lau, 2003), preoccupations and perceptions of risk are very different to those of early periods of modernity and pre-modernity. In pre-modernity, risks took the form of unavoidable natural hazards, while in classical industrial societies risks are seen as contingent on the actions of individuals and wider social forces (Goldblatt, 1996). By placing responsibility for risks in the hands of institutions, industrial society creates a system of rules to manage the impact of these risks. 
According to Risk Society theorists, contemporary risks that result from scientific and technological advances differ markedly from what is characterised in Beck's recent writings as ‘simple or first modern society’ (Beck et al, 2003: 28). As environmental risks are irreversible and cumulative they are seen to be more catastrophic than previous eras. Often they are imperceptible to human senses, are global in scale, and can act far from their origins (Beck, 1992). Attributing causality becomes problematic as the cause/ effect relationship is uncertain and contested. According to Beck (1992), once blame cannot be attributed, institutions become less important as the mechanism to cope with and mitigate risks. As a result, the role of modern institutions is increasingly challenged, with challenge eventually shifting to conflict between sections of society concerning environmental risks (Benn 2004).

Meanwhile risk decisions are opened up to a wider array of participants, outside of the traditional experts and regulators, to include individual citizens and has been opened up to a wider array of participants, outside of the traditional experts and regulators, to include outsider stakeholders, individual citizens and organisations, associations and movements (Beck, 1992; Matten, 2004). Shifts both in the themes and participants in the risk discourse indicate the transition from 'first modern society' to the 'Risk Society.'

Beck et al (2003) argue that as well as changes to social structures, (in large measure making them work for citizens, rather than above citizens) there is a revolution concerning the very notions of change itself. This revolution is due to the processes of reflexive modernisation . According to Beck: 
What is meant by that is not reflection on modernisation but 'reflexivity' in the sense of the unintentional, often unseen, calling into question, changing and cancellation of modernization by itself' (Beck, 1998: 132).

Reflexive modernisation is creating a distinct ‘second wave’ of modernisation associated with increasing awareness that control over contemporary versions of risk is impossible. In the 'second wave', attitudes towards problem-solving and the responses of institutions to risks and hazards reveal the inadequacy of current systems in terms of managing these new forms of risk. The unquestioned assumptions that formed the foundations of modernity are now being examined in terms of their rationality; it is this second-order rationalisation or reflexivity where practical knowledge is constantly revisable that is the hallmark of reflexive modernisation. It is the process that is driving the shift to the Risk Society.

Beck (1995) draws these concepts together to classify the Risk Society into stages. In its first stage, society attempts to implement controls or eliminate the risks through traditional institutional or economic means; in the second stage, confronted by a mounting institutional crisis, there is an attempt to implement more transformative change (Adams, 2001).The emergence of these 'manufactured' uncertainties (Giddens, 1994) is forcing society to rethink political and organisational structures and behaviour in order to better deal with these risks (Beck, 1992; Beck,1994; Beck,1997; Beck, 1999). As a result of the processes of reflexive modernisation, it is argued, modernity itself is challenged.

\subsection{Boundaries of choice}


Recently Beck and colleagues have analysed the 'meta-changes' in theory and institutions of the Risk Society through the lens of boundaries: between scientific and unscientific forms of knowledge, between the social and the natural and between social spheres in general (Beck et al 2003). In their words, this period can be characterised in terms of the following features concerning boundaries (2003: 19):

1. 'Boundaries cease to be given and instead become choices. Drawing boundaries becomes optional.

2. Simultaneous with that, there is a multiplication of the plausible ways in which boundaries can be drawn, as well as ways they can be drawn into doubt

3. The existence of multiple boundaries changes not only the collectivity defined by them but the nature of the boundaries themselves'.

Rather than the postmodern conception of dissolved boundaries, in this period traditional boundaries multiply and dissolve, but are replaced by pragmatically determined, temporary boundaries that are socially selected and optional.

In this more recently developed concept of the ‘fictive’ boundary, Beck builds on his earlier characterisation of 'sub-political' decision-making arrangements. His understanding of 'subpolitics’ refers to the temporary, multiple stakeholder decentralized and flexible arrangements and networks that he argues are increasingly taking over decision-making and are sites of legitimation and action in the Risk Society (Beck, 1997; Little, 2000). Examples are task forces, consultative committees and other such forms operating outside the traditional representative arena. Other writers (such as Dryzek, 1995; 1997; and Giddens 
1994) also see democratic potential in these arrangements. It is the boundaries of such forms that presumably Beck conceives of as fictive, boundaries that reflect choice rather than imposition.

\subsection{Individualization}

Risk Society theory makes broad claims concerning the delegitimation of the traditional leading institutions of modernity, such as corporation, state and the law, as a result of their perceived inability to deal with modernisation threats. In a reflexive, constantly shifting and multiple stakeholder arena, individuals and individual organizations are now returned to power in what Beck (1997: 98) has termed the 'non-institutional renaissance of politics'. The devaluation of modern institutions capability to manage the new themes of the risk discourse and expert knowledge has also impacted on the role of the individual. The increased access to knowledge on risk and the heightened degree of choice have imposed upon us what Boyd considers to be a 'new burden of risk assessment' (2003: 101), whereby individuals are engaging in the social construction of counter-expertise. This is what Beck (1999) terms ‘individualization’ and what Giddens (1994) refers to as ‘the disembedding of social institutions.

The notion of individualization is conceptualised as the other side of the coin of reflexivity. As traditional norms and expectations, the power of modern institutions and knowledge of experts are called into question by reflexive modernisation, individuals are adopting the responsibility of seeking and inventing new certainties for themselves (Tulloch and Lupton, 
2003; Goldblatt, 1996). Self-transformation occurs through the impact of both individualization and globalisation - the result is a loss of legitimacy for traditional institutions (Beck, 1999).

But this important concept of individualization, argued by Bauman (1993) to be Beck's most profound insight, is controversial and has been little examined empirically. Some scholars, for instance, argue that awareness raising through individualization of responsibility does not necessarily translate into empowered action. While the public is given a voice in decisionmaking processes in the new risk discourse and thus the opportunity to provide counterexpertise (Boyne, 2003), this voice may mean little if the public is not granted the power to enforce their opinions. The micro level actors may provide input in the decision-making process to treat the situation but unless there is collaboration between them, may not have the capacity to address the situation directly.

Risk Society theory has generated useful insights in a number of discourses: the sociology of risk (Irwin, 2001; Wynne, 1996), 'ecocentric' business models (Shrivastava, 1995), and changing forms of business communication, corporate responsibility and citizen participation (Demetrious, 2002; Livesey, 2001; Tsoukas, 1999). But while reflexive modernisation, Risk Society and individualization theories offer persuasive insights into the growing public concern for the effects of industrialisation on human health and that of the natural environment (Irwin, 2001; Wynne, 1994), they have been given little detailed empirical examination and a number of scholars have requested more evidence (e.g. Parkin, 1998). As Schlosberg (1999), a leading writer on environmental justice, puts it, Beck has paid little 
attention to finding real world case studies that demonstrate his theories. Having said that, Risk Society and its linked theories of individualization and reflexive modernity are highly complex concepts. In the case analysis in the following sections of the paper, we have therefore selected those aspects of these theories that can best explain the events of the case.

\subsection{Approach and Case Study}

This paper explores Risk Society themes through the HCB case study. In conjunction with evidence accumulated elsewhere in this volume, our empirical material derives from interviews with stakeholder representatives and independent observers, from documentary analysis, and from participant observation in stakeholder meetings held to negotiate management of the environmental risk.

The central issue of the case material analysed from various perspectives through this volume is the disposal of the 10,000 tonnes of HCB waste stored at the Botany Bay site of the Orica chemicals company in Sydney, Australia. It is the largest stockpile of this highly toxic organochlorine in the world, and responsibility for management of this waste is a highly contested issue, reflecting many of the key challenges characterising the broader concept of environmental sustainability. These challenges are such that three to four decades after the production of the waste, there is still no resolution on disposal location or methodology. An important phase of the dispute has been Orica's attempt to gain approval for an on-site treatment plant using the 'Geomelt' process (Brown, this volume). This ended in 2004 with the New South Wales State Government rejecting this proposal, and requiring 
Orica to find an alternative site in an unpopulated area. At the time of writing, no such site has been identified, and the option of exporting the waste to a European facility has become the latest, highly controversial, proposal (Brown, this volume; Rae and Brown, this volume).

As Rae and Brown point out, a number of different bodies formed to guide this decisionmaking have emerged since the Australian government rejected high temperature incineration as an option for the destruction of organochlorines in 1992. These bodies have included a National Advisory Body ( to the Australian Government), a Community Participation and Review Committee (CPRC) legislated for under the HCB Management Plan, a NSW Commission of Inquiry and an Independent Expert Panel, commissioned by the NSW Government. The conflicting attitudes of the many stakeholders involved in and represented by these bodies, compounded as they are by the scientific uncertainties associated with the alternative waste technologies and their impacts, are recorded in the papers in this volume. A key point in the lack of resolution of this dispute is not just that these voices are in conflict but that they represent the bounded rationality and identity of the various stakeholder groups. For instance, Benn and Jones (this volume) note that Orica's identity as a leading techno-scientific organisation is a source of power and legitimacy and therefore very much at stake in the negotiations as to whether disposal should take place on its site, under its stewardship. In a similar vein, local community groups have an identity forged by a history of worker/ company relations in the local area and a rationality shaped by Orica’s somewhat opaque previous community relations policies. Meanwhile Greenpeace, important as a key peak NGO involved in toxic waste issues at the Orica site, has an identity fixed by its traditional opposition to the transport of toxic waste. (However we can note that 
since the decision to abandon Geomelt on site at Botany, new Greenpeace focus on climate change issues effectively precludes its active campaigning on the HCB issue).

The challenges concerning disposal of the waste are also underpinned by changing social understandings of the role and nature of both expert knowledge and public participation in decision-making concerning environmental risk. Indeed one of the key outcomes of the case study is that Orica has been firmly placed as responsible for the wastes and as owners of the associated risks, but not as the final authority on how the wastes should be managed. Instead, that authority is dispersed across a range of decision forming structures, with the State Government having final say, ultimately through licencing arrangements. For example, when the New South Wales government ordered Orica to investigate other sites, it established an Independent Panel of three experts which continues to review and advise on all options. And considerable power also resides outside both company and government. For example, community members of the CPRC, charged under legislation to review the decision-making, have exerted strong political suasion: They rejected the advice of an independent expert which they themselves engaged, (though he was paid for by Orica), and they challenged the legitimacy of Orica's various public for a called during the environmental impact assessment process. As the firm acknowledges itself, this complexity sees the company reforming its public consultation and community engagement techniques and policies, as a precondition for decision making.

To sum this up, several contributing authors (for example Rae and Brown, this volume) have noted the inability of various levels of government to locate an appropriate role for 
themselves in the decision-making. In contrast, the dispute highlights the power that community-based organisations can marshal, particularly with the support of informal networks and information systems. Hence we see the key argument of the community representatives on the CPRC that the waste should not be destroyed in a highly populated area winning through.

\subsection{Risk Society Themes and HCB in Botany}

In categorising our qualitative data, we established the following themes related to the multiple stakeholder decision-making described in this case:

1. perceived type and source of risk,

2. power relations among stakeholders in the allocation of environmental risks,

3. public participation, policy and regulation

4. the role played by expert knowledge,

Table 1 compares the guiding factors of multiple stakeholder decision-making concerning environmental risk in conditions of industrial society to those in the two 'stages' of the Risk Society.

\section{Table 1 here}

In our analysis, we firstly tabulate the understandings of industrial society and Risk Society held by Beck and other Risk Society theorists theory according to these themes (See Table 1). We then compare these prescriptions with the observed events of the case study. We 
recognise the complexity of Risk Society theory and that it is impossible to capture in its entirety in this paper. But these key concepts are selected as they best explain the empirical case study.

\subsection{Perceived type and source of risk}

Two decades of frustrated decision-making concerning the disposal of the HCB waste stored at Orica illustrate key characteristics of the Risk Society. The waste itself was generated in association with 'scientific breakthroughs' of the industrial phase of organic chemistry. The struggle during the 1980s to reform the industrial system responsible for the production of toxic risk in Australia are characteristic of Stage 1 of the Risk Society. Largely as a result of the formation of a Community Participation and Review Committee (CPRC), with representatives from individual members of the community as well as environmental, industry and government representatives, individual actors became increasingly informed concerning the causes and nature of environmental risk. The role and responsibilities of the CPRC is a reflection of outside movements and associations becoming engaged in the decision-making process about risks, a characteristic of the move towards the Risk Society.

Both heightened perceptions of risk and the source of the risk in the Orica episode display characteristics of Stage 2 of the Risk Society. The rhetorical contest (Livesey, 2001) concerning disposal of the toxic waste reflects the struggle that corporations and government face as they are confronted by a reflexive public, newly aware of the 
dangers associated with industrial organic chemistry. Not only is HCB itself now widely recognised as highly toxic but the new disposal technologies for organochlorines such as HCB potentially produce toxic emissions which are imperceptible except through the assistance of experts and specialised technology (Beck, 1992; Tsoukas,1999). In contrast to earlier forms of risk, the disposal of the HCB poses risks at a global level acting far beyond the immediate vicinity (Goldblatt, 1996). As is typical for the Risk Society, the disposal of the HCB is perceived to be more threatening because of community resentment at a history of community deception by ICI/ Orica. It is seen to reflect the ongoing ‘organised irresponsibility' of government and corporate stakeholders. As community representatives Hillier et al argue (this volume: page 2): 'All these levels of government allowed Orica/ ICI to continue making the products which were creating this toxic waste'.

Many of the theorised characteristics of the Risk Society decision-making relate to high levels of uncertainty concerning the level of risk. The Geomelt process proposed by Orica for disposal of the waste has many uncertainties including the nature and extent of the emissions from that amount of HCB and the length of time for its disposal. This uncertainty and unpredictability is a central feature of reflexive modernisation (Boyne, 2003) which is driving the move towards the 'Risk Society.' Such unpredictability makes it unlikely that the Geomelt procedure can be insured; Orica's survival as a firm is perceivably threatened. The hallmark of the Risk Society is the dissolution of institutions that once operated without their legitimacy being questioned (Goldblatt, 1996). In this case, we hear members of the Botany community questioning whether issues of insurance and liability are the underlying reasons for the ICI head office 
disposing of its Australian operation and could result in Orica terminating its business operations in the future (Hillier et al, this volume).

3.2 Power relations among stakeholders in the allocation of environmental risks

A staged emergence of new conditions of risk and of changing power relations is seen in the study. In Stage 2 of the Risk Society, complex 'sub-political' arrangements develop outside the representative realm, in an attempt to deal with risks which are characteristically ambiguous and readily politicised (Beck, 1999). The events in the Orica HCB dispute shows sub-politicization as challenging corporate power (Beck ,1999: 108); the CPRC putting Orica in a situation where conditions of suspended doubt could easily shift to mistrust (McDonell, 1997; Rae and Brown, this volume) Trust and reputation are the determinants of acceptability of the disposal technique to the risk community. So even though the community, company and government all initially welcomed the HCB Plan and its CPRC, in the end this structure challenged both corporate and government power. As Hillier et al (this volume) point out, the CPRC became a vehicle for informing the wider community and a critical platform from which to approach the media and highest levels of national government.

The study shows that new arenas for dispute and agreement, for networking and negotiation, are developing as strong shaping forces on toxic risk management. These new social arrangements are now sited in local, decentralised, temporary and less structured arenas of decision-making such as the new Expert Review Panel and the CPRC. 
The case reflects the dissolution and temporary reforming of boundaries that theoretically distinguishes Risk Society from both industrial and postmodern society (Beck et al, 2003).For nearly a decade the CPRC attempted to reach a decision on how and where to dispose of the waste. The failure of this decision-making highlights emergent problems associated with multiple stakeholder decision-making associated with responsibility for the risks of disposal . It further highlights boundary disputes over Orica’s right to control the decision-making. As Hillier et al (this volume) make clear, the community now challenges this right. This aspect of the case plays out Beck's analysis (Beck et al , 2003: 22) of the nature boundaries in the Risk Society - Orica's boundary between its actions and society is no longer so firmly set by a self-determined corporate identity. The boundaryless organisation does not just refer to an organisation with a more flexible internal structure but one that is required by society to open its decision-making to give it a 'licence to operate'. The boundary is thus under constant negotiation - as Beck et al (2003: 22) put it: 'fictive, conscious and temporary’.

However, the study lends only qualified support to the Risk Society Stage 2 concept that power relations are mainly concerned with the distribution of risk. The local residents display a lack of trust in Orica sourced not only in the firm's failure to manage environmental risks responsibly but in a history of adversarial relations with industry. Until relatively recently, government and industry were able to maintain their position of 'organised irresponsibility' (Beck, 1992) concerning toxic risks. Various urban policy decisions described by James ( this volume) illustrate the attempts by government and 
industry to mask the origins and consequences of late industrialisation - the hallmark of organised irresponsibility (Goldblatt, 1996). The period of indecision over the disposal of the waste between 1997 and 2004 indicates the progressive paralysis of traditional forms of representative government in terms of their capacity to manage the heightened public awareness concerning such risks. The episode illustrates Beck's point (1995) that the outcomes of 'sub-political ' forms of decision-making will be ineffectual if made subservient to traditional forms of government. Even though the Commission of Inquiry was thought to be the final court of review, it was overturned. It was not until the Independent Panel of 2004 recommended and gained Ministerial agreement, that Orica accepted that the waste not be destroyed on site. Taking on the challenge proposed by Beck (1992; 1995) it is clear that only a completely new set of political conditions will enable the threats from chemical technology to be forestalled.

The stalemate in decision-making supports Beck's theoretical proposition that congestion is the key source of citizen power in such disputes. With a situation where even the state government member for Botany was questioning the decision-making process (Hillier et al, this volume), the case illustrates how conflicting claims by a few central actors from the reflexive risk community, exemplified by the CPRC, can paralyse representative government and challenge its legitimacy, thereby contributing to the erosion of modern social institutions. Our case highlights the inherent paradox of 'organised irresponsibility' - as Goldblatt puts it (1996), even though the organisations that are the source or cause of hazards, such as Orica or ICI, may have the true sense of the likely implications of their actions, the demonstration of proof lies in the hands of those afflicted (Goldblatt, 1996). 
A key tenet of Risk Society theory is that citizens become more preoccupied with the distribution of risk than with the distribution of wealth; this becomes the source of conflict, between industry and industry, as well as between local communities and industry. The difference between classical modernity and reflexive modernity is the change in focus from wealth and power towards a society characterised by risk and uncertainty (Boyne, 2003). Intersectoral disputes were initially evident in the disagreement, between Orica and nearby breakfast food manufacturer Kellogg, which surfaced at the Commission of Inquiry (Jensen-Lee, this volume). However, the perceived breaches of trust between the two corporations now appear more easily resolved than those between the local residents and the corporation: In recent manoeuvrings, Kellogg has declined to align itself with residents and Botany Council in oppositional campaigning, preferring instead to make its own representations to government, and apparently dealing directly with Orica behind the scenes. Such recent cooperation between the companies belies Risk Society concepts of a society characterised by an over-riding preoccupation with risk.

The study does not support Risk Society arguments which link high levels of uncertainty to high levels of influence from mediatised systems. It appears national actors with high symbolic capital (Tsoukas, 1999) are needed for the influence to be generated. Greenpeace's minimal participation in the Orica debate has been one influence on the level of public awareness of the dispute, keeping it at the local level. Further, the risk issue has lost its global significance in the public eye, since to date recommendations by decision-makers have supported a local, decentralised solution of 
disposal on site. Even the making of a nationally screened documentary film was prompted by the desire, on the part of the film's director, to explore a local or grass roots response to globalisation, and to explain 'how civil society works', rather than to shift the HCB debate into a national arena.

This appears to be one of the downsides of the individualization of society. The individual actor does not have the power to enforce change over a large problem, as the aggregation of consequences at a macro-level proves to be too much for smaller stakeholders. The case thus plays out Beck et al's (2003) characterisation of a complex multiplicity of networks and subject boundaries, of individuals, collectives and institutions which is inherently difficult to coordinate; one of the associated features in reflexive or second modern society.

\subsection{Role played by expert knowledge}

The changing and ambiguous role assigned to science in the Risk Society is borne out in the events of the study. We see a shift from the pre-1980s scenario where science legitimates the externalising of environmental costs by industry to a situation where local knowledge, developed as a result of the individualization of risk, can authoritatively challenge both corporation and government assessments of safety. The ambiguity lies in the fact that while the uncertainties associated with the disposal have resulted in an increased reliance by the local risk community on scientific experts, this 
dependence is parallelled by an emergent distrust. This is characteristic of the Risk Society, where expert knowledge loses its privileged position (Boyne, 2003).

Reflexivity is evident in that local members of the community did challenge the opinions of experts, engage in the decision-making process and construct their own expertise. Their membership of the CPRC and the actions taken in order to fulfil these responsibilities raised their awareness of risks associated with toxic chemicals and led a number of the community to revise their opinion of institutions previously perceived as legitimate, such as the state and national governments and scientific expertise. In Beck’s analysis of Risk Society (eg 1992), the negative impacts of industrial processes, such as the community issues of dealing with toxic waste, acts to challenge the assumptions of modernity that science and traditional institutional mechanisms could avert the negative impacts of industrialisation. The challenge to the consensus or closed circle of experts, such as the chemical engineers of Orica and the external advisor paid for by Orica, was conflict over knowledge. The CPRC became a polarised network in dissent concerning the knowledge-based appraisal of risk, illustrating processes of 'nonlinear’ or reflexive modernisation (Beck, 1998: 96). According to Beck, the shift from liner to non-linear modernisation occurs when closed or homogeneous experts groups can no longer manage to exclude other forms of knowledge (Beck, 1998).

The case also illustrates Beck's analysis of the relationship between knowledge and trust. As Orica's communications have not generated the symbolic capital needed to convince local residents in the discursive struggles over the disposal on site. Scientific 
knowledge did not ensure trust in the 'external' experts brought in as EIS consultants, or as contributors to the Commission of Inquiry. Indeed, as Jensen-Lee points out (this volume), the various community and environmental group submissions to the Commission of Inquiry were united in their expressed distrust of Orica's framing of Geomelt as 'safe, in control' and therefore of low risk'). Also, when 'independent' expertise was lent to residents (Healy, this volume), this was no guarantee of trust in science, since residents dismissed their own experts' findings as tainted by Orica's apparent appropriation of his advice (Rae and Brown, this volume).

Playing out Giddens' (1994) understanding of reflexivity, 'expert opinion' had marshalled an attempt to reorder and redefine the conditions of the production of toxic risk by chemical technology in the service of corporations such as Orica. The corporate norm that accepted the externalising of such risks was challenged.

\subsection{Public participation, policy and regulation}

The events of the study broadly follow the pattern traced in Table 1, showing a shift from the command and control legislation pre-1980s to the largely symbolic attempts at reform during the 1980s to a regulatory regime which incorporates reflexivity as a key goal. The National Advisory Body and the National Waste Management Plans formulated by the Australian Government for the disposal of the waste in the 1990s are examples of formalised reflexive regulation which are designed to enable reflection and to generate a self- regulatory system for the management of the waste disposal. 
The protagonists in the risk community demonstrate the individualized reflexivity characterized for the Risk Society (Beck, 1999; Giddens, 1994). In this case, with the state government not perceived as either capable or willing to manage the risks associated with the disposal, or to contribute resources, the citizens see themselves as responsible. The blame is projected outwards as reflexivity and also internalized as individualization (Tulloch and Lupton, 2003). The Botany residents, members of the CPRC, are reflexive, but highly individualised. Indeed, supporting Beck's point (1997), structures such as the CPRC force the local community to take responsibility for managing the risk. But in this case the local community is not empowered by such structures as Beck envisaged (1997). Empowerment is linked to credibility and legitimacy of knowledge claims as well as to the necessary economic resources enabling democratic processes such as intra-group communication; here the individualized reflexivity of the local actors has been easily portrayed by their opponents in the discursive struggle as NIMBY (Hillier et al, this volume).

The study indicates a staged shift in corporate accountability. The Orica episode reveals a key player in the chemicals sector in Australia struggling to deal with new issues of accountability. Reflexive citizens expect more from corporations than new products or economic return (Giddens, 1994). As Rae and Brown point out (this volume), the Botany area, with its long history of industrial accidents and associated lack of trust was a fertile ground for the development of such a community. The establishment of the National Waste Management Plans by the Australian Government in the 1990s marked an attempt by the national government to ensure accountability. Heightened public perception 
of the risks associated with HCB disposal has forced the previously dominant corporate and governmental interests to delegate authority to the 'sub-political' realm. Rather than the regulatory agency steering and supervising the decision-making, with the Orica episode, the CPRC took on a role new for the public in this dispute: to review and advise, including monitoring of the implementation plan (Rae and Brown, this volume). As Benn and Jones argue (this volume), Orica's managers perceive their new situation of accountability to the CPRC as a newly threatening source of risk. Beyond the understanding of the increasing importance of symbolic capital in such conditions of increased corporate uncertainty and transparency, reflexive modernisation and Risk Society theory has a limited understanding of contemporary shifts in corporate accountability, neglecting, for instance, the process of identity creation and its implications for 'sub-political' decision-making on risk. The Orica episode shows each of the actors intent on image construction, each aware of the importance of credibility in the discursive 'sub-political' arena. Orica's determination to construct an image for itself as a corporate citizen of the Botany community does not align with its unreconstructed internally perceived identity as a technoscientific organization. Orica attempted to change its image and to break down the fortress-like barriers between itself and its stakeholders. But strong cultural aspects associated with its longterm identity did not change. The non-alignment of corporate identity and image is a major source of the distrust evident in the dispute. In this sense, identity is a key factor influencing this decision-making, one that was not explored by Beck in his earlier writings.

Beck's interpretation of individualization theory is fruitful as a means of understanding the events of this case (Beck and Beck-Gernsheim, 2002). Orica, the company, is the 
result of individualization, formed as the result of the 'vertical disintegration' of ICI Ltd as the firm outsourced its governance functions (Lash, 2002). As Bauman (2002) and Beck and Beck-Gernsheim (2002) have argued, individualization means disembedding from specified roles and functions without re-embedding. However, the struggle within the CPRC indicates the importance, somewhat neglected by these writers, of identity in the disembedding/ re-embedding process. So we see the discourse of the local residents drawing on Orica's (or ICI's traditional identity as the authoritarian employer. In the words of Hillier et al (this volume: page 5): 'Botany residents had never won before but this company was to be made more transparent through this issue' Orica looks back to its identity as the hierarchical, technoscientific firm, resorting to old patterns of 'industrial rational control' and the 'revolving door' between science and industry in its positivist perspective on risk assessment (Beck, Giddens and Lash, 1994; Beder, 2001). The Orica case displays evidence of reflexivity, the process that is driving the move to the Risk Society; therefore perhaps we are witnessing the progress towards the Risk Society, but we have yet to arrive at the destination.

The emphasis placed by all stakeholders on constructing and maintaining their identity as individual actors, has meant that the various bureaucratic decision-makers, Orica, government bodies, other corporations, and the various NGOs, have focussed on 'consultation - not participation' (Jensen-Lee, 2003: 38). Effectively, it is the struggle for identity formation which has lessened the democratization of risk, so much a feature of the optimistic predictions for the Risk Society. 
For example, Greenpeace's identity is of an international environmentalist organisation. Its support for local activists is therefore compromised by its long term and very public opposition to the transport of toxic waste and thus implicit support for disposal on site. The identity of the local community groups and residents is strongly personified in the leading activist - a very local personality. This has enabled the opposition to disposal on site to be characterised as NIMBY by other stakeholders.

Most importantly, however, the extent to which structures such as the CPRC can go beyond creating congestion and facilitate a more democratic allocation of environmental risks appears dependent on the financial resources available to the community members. Access to scientific and technological expertise was an economic, rather than a discursive issue. In this sense, the study raises questions of environmental justice, and economic or class concerns in the determination of risk, challenging the claim that 'democratic' risk emerges from negotiation in the 'sub-political' realm.

\subsection{Conclusion}

This paper broadly supports key propositions of Risk Society theorists. These include the characteristics of new forms of risk and the role played by scientific knowledge in risk disputes. Lay actors, in this instance the local residents of the Botany area around the Orica chemicals plant, show an increasing preparedness to engage with the technical debate on toxic risk, and to challenge the status of scientific expertise. This aspect of the study supports Risk Society proponent's claim that the reflexivity of modernity empowers laypeople to 
challenge established forms of expertise (Beck, 1999; Giddens, 1991); at the same time these actors display an acceptance of the value of technical expertise (Bauman, 1993). They reflect a key precept of the Risk Society: the development of an individualised reflexivity based on the need to protect oneself against the risk-inducing actions of government, science and industrial development (Bauman, 1993). But is the reflexivity of the Risk Society radical enough to challenge and overturn the taken-for-granted assumptions which community, corporate and other organizational actors hold about the industrial phase of society (Pollner, 1991)? Charged with monitoring their own safety through the establishment of the CPRC, the risk community studied here becomes necessarily concerned with the local effects of the disposal of HCB, rather than a broad-ranging and radical socio-political critique of the conditions and effects of industrialization (Pollner, 1991).

However, the case clearly shows the staged development of a 'sub-political' arena in which the legitimacy of corporate and government actors is challenged and decisionmaking paralysed. As Risk Society theorists have argued, we see that the new legitimacy accorded to the knowledge-based discourse of lay actors in 'sub-political' decision-making arenas can break the axis of power between corporation and government characteristic of industrial society. The increasing influence of the selfdetermining, non-representative 'sub-political' arena emerges as a strong theme. But the study also indicates that Beck's predictions concerning the empowering aspects of self determining 'sub-political' arrangements are overly optimistic. Not only does the individualized reflexivity described here not aim for profound challenge to the rationality of industrial society, but the responsibilities of the local risk community, thrust on them through the CPRC, in combination with the lack of strong public support 
from the international environmental NGOs, have meant that the local residents have been branded as NIMBY. Loss of power in the discursive struggle is the result. It seems the outcomes of 'sub-political' decision-making in reflexive modernization are dependent on the relationship between the individualized reflexivity of local actors and the more radical, global perspective associated with global organisations such as Greenpeace. The importance of localism emerges strongly in the study; yet as a concept is missing from Risk Society analysis of 'sub-politics'.

Other researchers have argued that key themes in the communications between stakeholders in the siting of hazardous waste facilities are identity disruption, mistrust and polarization (Welcomer, Gioia and Kilduff, 2000). This paper, too, shows the influence of such postmodern themes on stakeholder communication in the 'subpolitical' arena concerning risk, particularly the polarising effect that individualised image construction has on the stakeholders. It highlights the implications of lack of alignment between image and identity for the development of distrust and conflict, in turn preventing a more participative resolution. Actors in the CPRC dispute are seen to be constructing and maintaining their image and their symbolic capital as individual actors to an extent that prevented more participatory decision making: Orica as a technoscientific firm, the community members as representative of local interests, and Greenpeace as the international NGO, identified with the campaign against the transport of toxic waste. One of the strongest points of affirmation for Beck's theory of 'subpolitics' is that of all the major stakeholders, it is the national government which is least involved in the decision-making after the initial Plans were formulated. State 
government, too, has preferred to devolve responsibility for forming (as opposed to making) its decision to external consultative committees, such as the new Panel.

Secondly, the study highlights some important issues for organizational survival that are not dealt with either in Risk Society theory or in recent studies of organizational progress towards broader stakeholder engagement. We see the possibilities for loss of organizational legitimacy, if internally conceived identity and externally perceived image are not aligned in their negotiations on the allocation of environmental costs (Melawar and Jenkins, 2002; Scott and Lane, 2000). Both Orica and government have lost credibility as a result of this dispute. The self-perception of Orica, based in technoscientific rationality, is not aligned with its newly determined external image of transparent communicator. Given the difficulties in managing employee identification with a change in corporate identity (Andriopoulos and Gosti, 2001; Meijs, 2002), it is not surprising Orica's identity has remained that of a technoscientific organisation. Orica's problem is that in a reflexive community technoscientific status no longer legitimises the creation of risk.

Government also wears two faces in its involvement in the dispute, relating to the different roles played by the national and state governments. Despite early advances made at the national level in the participative development of the National Plans, the current stalemate is a result of a lack of alignment between the nationally set agenda and the capability of the state government to carry it through. Greenpeace, on the other hand, keeps its image and identity as an international campaigner against the transport 
of toxic waste firmly in alignment. The theme of identity is one of the post-modern condition, reflecting the shrinking importance of unitary and centralising themes. The influence of such postmodern themes as localism and identity challenges the neomodernist focus on risk argued for in Risk Society theory.

Overall this study demonstrates the fundamental incompatibility of the existing decision-making tools of representative governments and silo-like bureaucracies with the political pressures associated with issues of democratic access to knowledge, trust and individualised reflexivity evident in the ongoing dispute over the disposal of the HCB waste. Yet these structures still wield the ultimate control because of their capacity to address resource imbalances. The lack of trust between the firm and the local community and the unwillingness of the local community to bear the risk of toxic waste management on behalf of the collective demonstrates the issues of governance emerging in the individualised, Risk Society. Governments, corporations and NGOs have become increasingly concerned with issues of credibility, trust and consent working within the 'sub-political' arena, a concept drawn from Risk Society theory which the study shows to have considerable validity. In further work, it would be fruitful to analyse the 'subpolitical' arrangements between these stakeholders according to the way language constitutes multiple stakeholder negotiations concerning risk (Putnam and Fairhurst, 2001).

In this era of individualization, there are few support programs for groups low in cultural or knowledge capital who must now manage their own safety in relation to 
environmental hazards. So in the end, we have to take a major point from Beck, that of the fading of the state, still determined to cling to the reins of power, but not prepared to take the risk in decision-making when faced with individual corporations, communities and NGOs determined to protect their own reputation or image. For corporations who have built their success on an internal identity linked to the surety of values such as technoscientific credibility there are major questions of survival in a risk-averse and litigious society. The challenges for the democratic state in achieving the local, decentralized solutions to the Risk Society, in the face of these boundary issues, are profound.

\section{References}

Adams, W. M., 2001, Green Development. 2nd edition. London, Routledge

Andriopoulos, C. and Gosti, M., 2001, Living the corporate identity: case studies from the creative industry. Corporate Reputation Review, 4: 2, 144-154.

Bauman, Z., 1993, Postmodern ethics. Oxford, Basil Blackwell.

Bauman, Z., 2002, Preface in: U. Beck and E. Beck-Germstein, Individualization. London, Sage Publications.

Beck, U., 1992 (trans. Mark Ritter). The Risk Society. London:, Sage.

Beck, U., 1995, Ecological politics in the age of risk. Cambridge, Polity Press.

Beck, U., 1997, The reinvention of politics. Cambridge, Polity Press.

Beck, U., 1998. Democracy without enemies. Polity Press, Cambridge. 
Beck, U., 1999, World Risk Society. Cambridge, Polity Press.

Beck, U. and Beck-Gernsheim, E.,2002, Individualization. London, Sage Publications.

Beck, U., Bonss, W. and Lau, C., 2003, Theory, Culture \& Society 2003, SAGE, London, 20 (2), 1-33

Beck, U., Giddens, A. and Lash, S., 1994, Reflexive modernisation: politics, tradition and aesthetics in the modern social order. Stanford, Stanford University Press.

Beder, S., 2001, Global spin, Melbourne, Scribe Publications.

Benn, S. Interview with Site Manager, Botany Industrial Park. (comprising the organisations Orica, Quenos and Hunstman). Sydney: Botany, 30 November 2001).

Benn, S. Interview with Community member of CPRC. Sydney: Botany, 11 June 2002.

Benn, S. 2004, Managing toxic chemicals in Australia: a regional analysis of the risk society. Journal of Risk Research, 7, 277-296.

Benn, S. and Jones, R., this volume, The Role of Symbolic Capital in Stakeholder Disputes: intractable decision-making concerning intractable wastes.

Boyne, R., 2003, Risk. Open University Press, Buckingham, UK.

Brown, P., 1999, Our affair with hexachlorbenzene: a case study in Australian chemicals management. The environment: risks and opportunities. Third Annual International Public Policy and Social Science Conference, Oxford.

Brown, P., 2002, The Ratbag of Botany: Activism and Community Participation around industrial sites in southeastern Sydney. In: McPhillips, K. (ed.) Local Heroes: Australian crusades from the environmental frontline. Pluto Press, Sydney.

Community member of CPRC. Public meeting CPRC, Botany Town Hall, December 2003. 
Cripps, D.J., Peters, H.A., Gocmen, A. and Dogramici, I., 1984, Porphyria turcica due to hexachlorobenzene: a 20 to 30 year follow-up study on 204 patients, British Journal of Dermatology, 111, 413-422.

Delanty, G., 1999, Social Theory in a Changing World. Cambridge, Polity Press.

Demetrious, K., 2002, Grassroots energy: A case study of active citizenship and public communication in Risk Society. Journal of Communication Management, 7 (2), 148-155.

Dryzek, J., 1995, Political and ecological communication. Environmental Politics, 4, 13-30.

Dryzek, J., 1997, Politics of the earth: environmental discourses. London, Oxford University Press.

Dunphy, D., Griffiths, A and Benn, S., 2003, Organizational change for corporate sustainability. London, Routledge.

Dunphy. D. and Stace, D., 2001, Beyond the boundaries: leading and re-creating the successful enterprise. Sydney, McGraw Hill.

Giddens, A., 1990, The consequences of modernity. Cambridge, Polity Press.

Giddens, A., 1991, Modernity and self-identity: self and society in the late modern age. Cambridge, Polity Press.

Giddens, A., 1994, Beyond Left and Right. Oxford, Polity Press.

Giddens, A., 1998, The Third Way. Cambridge, Polity Press.

Goldbaltt, D., 1996. Social Theory and the Environment. Polity Press, Cambridge. Irwin, A., 2001, Sociology and the environment. Cambridge, Polity Press. Jensen-Lee, K., 2003, Orica, HCB and Geomelt: the Commission of Inquiry for Environment and Planning into Orica's proposal to build a HCB waste destruction facility at 
Botany using Geomelt technology. Working Paper. Sydney: School of Social Science and Policy, UNSW, Sydney.

Keneally K., 2003, Planning Minister should listen to local residents on HCB waste. Media Release from Member for Heffron. Sydney 22 June.

Little, A., 2000, Environmental and eco-social rationality: challenges for political economy in late modernity. New Political Economy, 5: 1, 121-136.

Livesey, S., 2001, Eco-identity as discursive struggle: Royal Dutch Shell, Brent Spar and Nigeria. Journal of Business Communication, 38: 1, 58-89.

Lloyd-Smith, M., 2001a, HCB community information system. Available at: http://www.oztoxics.org/ (accessed 15 July 2001).

Lloyd-Smith, M., 2001b, National Toxics Network Alert. Available at: http://www.oztoxics.org (accessed on 2 July 2001).

Lloyd-Smith, M., 2001c, Doctoral review, Faculty of Law, University of Technology, 12 December.

Matten, D. 2004. The impact of the risk society thesis on environmental politics and management in the globalizing economy. Journal of Risk Research, 7, 377-398.

Meijs, M., 2002, The myth of manageability of corporate identity. Corporate Reputation Review, 5: 1, 20-34.

Melawar, T. and Jenkins, E., 2002, Defining the organising identity construct. Corporation Reputation Review, 5, 76-90.

McDonell, G., 1997, Scientific and everyday knowledge: trust and the politics of everyday initiatives. Social Studies of Science, 27, 819-863. 
NAB and Scheduled Wastes Management Group. Solutions, 2000, Canberra, Environment Australia.

Parkin, A., 1998, Book notes: political philosophy and methodology. Political Studies, 46: 4, 842.

Pollner, M., 1991, Left of ethnomethodology; the rise and decline of radical reflexivity. American Sociological Review, 56, 370-80.

Putnam, L. and Fairhurst, G., 2001, Discourse analysis in organizations: issues and concerns. In: F. Jablin and L. Putnam (eds). The new handbook of organizational communication. Thousand Oaks: Sage Publications, pp. 78-136.

Schlosberg, D., 1999, Environmental justice and the new pluralism, Oxford, Oxford University Press.

Scott, S. G. and Lane, V.R., 2000, A stakeholder approach to organizational identity. Academy of Management Review, 25, 43-62.

Shrivastava, P., 1995, Ecocentric management for a Risk Society. Academy of Management Review, 20: 118-137.

Tsoukas, H., 1999, David and Goliath in the Risk Society. Organisation, 6:1, 499-528. Tulloch , J. and Lupton, D., 2003, Risk and Everyday Life. Sage Publications, London. Welcomer, S.A., Gioia, D.A., and Kilduff, M., 2000. Resisting the discourse of modernity: Rationality and emotion in hazardous waste siting. Human Relations, 53: 1175-1205

Woodward Clyde Consultants, 1996, ICI Botany Groundwater Stage II Survey. 
Wynne, B., 1996, May the sheep safely graze? A reflexive view of the expert-lay

knowledge divide. In: S. Lash, B. Szerszynski and Wynne, B. Risk, Environment and Modernity. London: Sage, pp. 44-83. 
Table 1: Factors guiding multiple stakeholder decision-making

\begin{tabular}{|c|c|c|c|}
\hline & Industrial society & Stage 1 of the Risk Society & Stage 2 of the Risk Society \\
\hline Perceived type and source of risk & $\begin{array}{l}\text { Naturally occurring threats; fatalistic } \\
\text { acceptance of natural disasters }\end{array}$ & $\begin{array}{l}\text { Increasing uncertainty concerning } \\
\text { effects of scientific advances and } \\
\text { technological innovation }\end{array}$ & $\begin{array}{l}\text { Through increased influence of } \\
\text { mediatised systems, recognition that } \\
\text { science and technology may create } \\
\text { unknown dimensions of risk }\end{array}$ \\
\hline $\begin{array}{l}\text { Power relations among stakeholders } \\
\text { in the allocation of environmental } \\
\text { risks }\end{array}$ & $\begin{array}{l}\text { Traditional political arrangements of } \\
\text { representative democracy; } \\
\text { Unquestioning support for } \\
\text { technological development and } \\
\text { modernisation; conflict concerning } \\
\text { distribution of wealth; 'organised } \\
\text { irresponsibility' by government, } \\
\text { corporation, law and science; }\end{array}$ & $\begin{array}{l}\text { Social protest raises awareness and } \\
\text { uncovers areas of risk; hazards begin } \\
\text { to develop as political subjects; } \\
\text { challenges to existing hegemony of } \\
\text { science, technology and business } \\
\text { interests; institutional failure; Social } \\
\text { protest from the margins of } \\
\text { corporatist arrangements; struggle of }\end{array}$ & $\begin{array}{l}\text { Individualised reflexivity; } \\
\text { emergence of sub-politics; } \\
\text { ecological issues and large scale- } \\
\text { hazards come to dominate political } \\
\text { and moral arenas; conflict over } \\
\text { distribution of risk; conflicting } \\
\text { claims by the array of organisations } \\
\text { within the sub-political arena }\end{array}$ \\
\hline
\end{tabular}




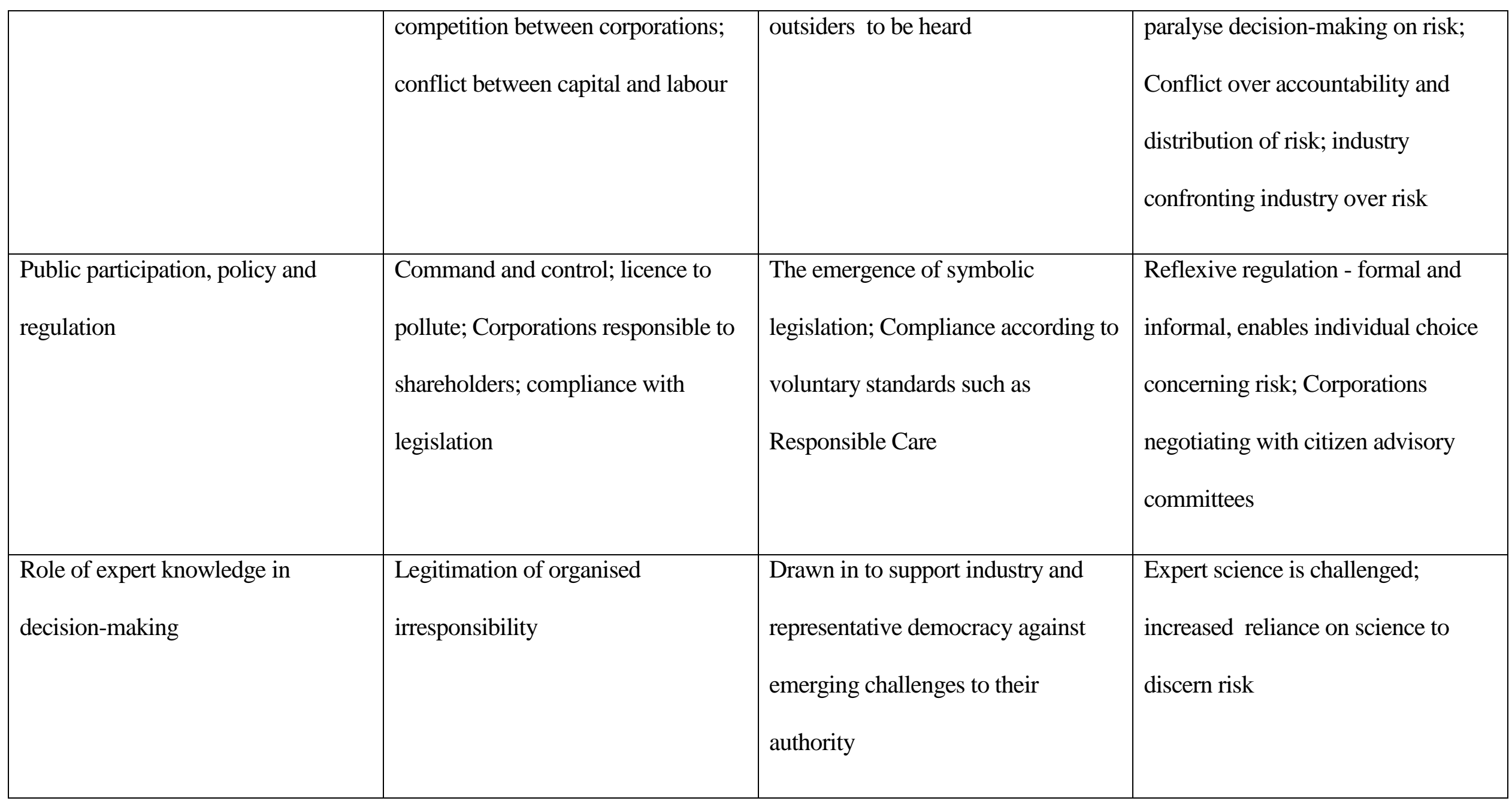


Table 1 (cont)

\begin{tabular}{|l|l|l|l|}
\hline & Industrial society & Stage 1 of the Risk Society & Stage 2 of the Risk Society \\
\hline
\end{tabular}

